\title{
Determinants of Regional Budget Absorption in the Regional Apparatus Organization of Palembang City
}

\author{
Vega Nabila Putri ${ }^{1}$ Kuo Keo Pisey ${ }^{2}$ Mardhiah $^{1}$ Rita Martini ${ }^{1, *}$ \\ ${ }^{1}$ Accounting Department, Polytechnic State of Sriwijaya, Palembang 30139, Indonesia \\ ${ }^{2}$ Entrepreneurship Development Institute, CIEDI Cambodia-India, Cambodia \\ ${ }^{*}$ Corresponding author. E-mail: ritamartini@polsri.ac.id
}

\begin{abstract}
This study aims to investigate the effect of budget planning, budget execution, goods / services procurement, and competence of human resources on budget absorption in the regional apparatus organization of Palembang City. The data used are primary data. The sample selection technique was purposive sampling, totaling 87 respondents who held the positions of Head of Finance Subdivision, Head of Planning and Treasurer of Expenditure. Data were analyzed using descriptive analysis, instrument test, test of classical assumption, analysis of multiple regression, coefficient of determination and hypothesis testing. The results showed that partially budget planning, budget execution, and procurement of products / services had a big effect on budget absorption, while human resource competence had no effect on budget absorption.
\end{abstract}

Keywords: good government governance, government accounting.

\section{INTRODUCTION}

Regional autonomy has given authority to local governments in regulating and managing their own government affairs. This opens up opportunities for local governments to meet their needs according to the priorities of each region. This effort is aimed at improving the quality of public services in creating better governance (Martini et al, 2019). After the implementation of regional autonomy and the existence of transparent and accountable financial reports as a variety of government accountability to the general public. The Regional Revenue and Expenditure Budget (APBD) is in the spotlight of the community to see the results of government performance, in realizing the APBD is in accordance with what is expected by the community. The dynamic and scheduled budget absorption process also supports the smooth process of regional development and economy.

The poor quality of budget absorption will have an impact on the national economy as a whole (Sudasri, 2016). First, the ineffectiveness of the function of fiscal policy in order to increase economic growth effectively. Second, the loss of the benefits of spending because not all of the funds that have been allocated can be utilized, which means there is idle money. Third, the delay in implementing government performance programs related to poverty reduction. Finally, accumulating bills at the end of the fiscal year is very unhealthy for government cash management.

The budget in the city of Palembang in 2018 and 2019 in the first quarter was only absorbed by $15.45 \%$ and $10.45 \%$, this can be said that the absorption of the Palembang city government budget has not met the ideal absorption pattern of $25 \%$ in the first quarter. in 2018 it reached $90.77 \%$ and in 2019 it reached $85.58 \%$. Budget absorption in 2019 has decreased compared to 2018 of $5.19 \%$. The budget absorption within the city government of Palembang has the remaining unrealized budget in 2018 of $9.23 \%$ and in 2019 of $14.42 \%$. The slow absorption of the budget (Martini et al, 2020) resulted in an exceedingly loss of expenditure benefits, because the funds allocated were not fully absorbed.

Researchers are motivated to conduct this research because there are many delays in budget absorption that occur in Indonesia. This research is expected to measure the success of the country in optimizing budget absorption and to find out how much influence the variables related to budget absorption have. 


\section{LITERATURE REVIEW AND HYPOTHESIS DEVELOPMENT}

Halim (2016: 92) explains that budget absorption is the achievement of an estimate to be achieved during a specific period of time at a specific time (the realization of the budget).Planning as a reference for budgeting is basically a process for preparing an income, expenditure and financing plan for a certain period of time (Zaenur, 2017).According to Ramdhani and Zaenur (2017), "budget execution is an effort to realize the budget planning that has been made. Budget execution is also an activity carried out in relation to the use of the budget. Presidential Regulation Number 16 of 2018 concerning Government Procurement of Goods / Services, confirms that the procurement of goods / services government could be an important part of the method of implementing development, namely to boost public services and develop the national and regional economy. Competence (Sutrisno, 2019: 203), is a basic characteristic of a person that enables him to provide superior performance in certain jobs, roles, or situations.

The research framework developed is presented in Figure 2.

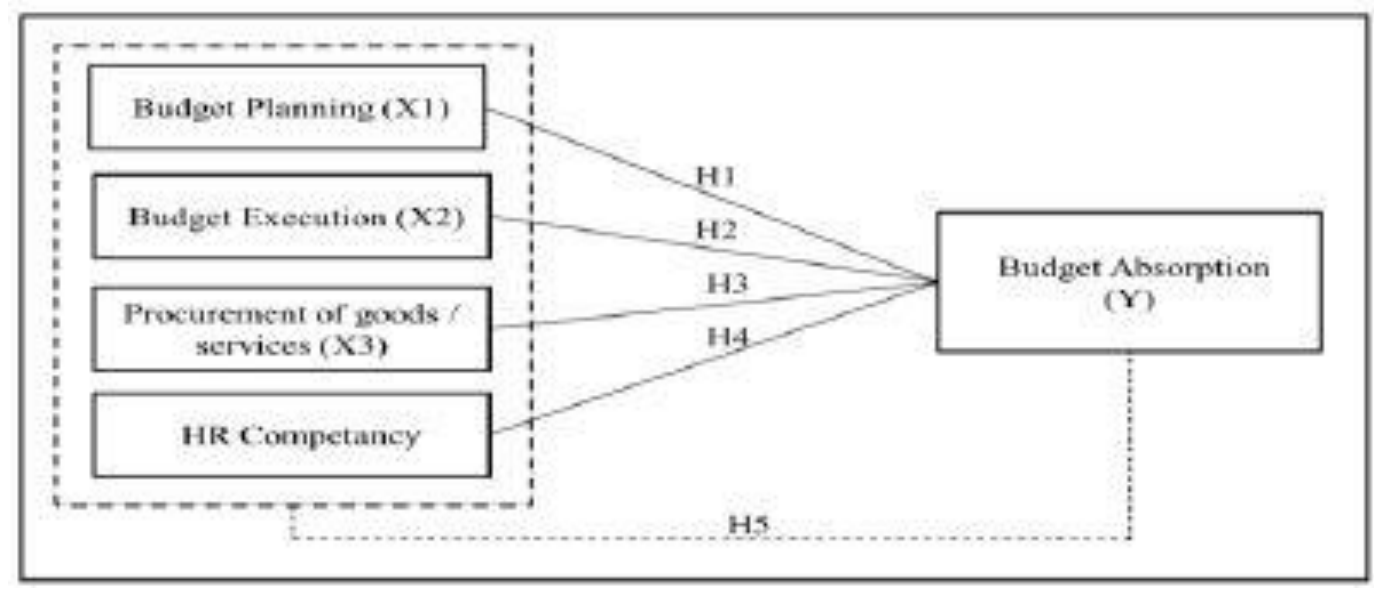

Source: Data processed, 2020

The research hypotheses compiled include:

H1: Presumed budget planning affects the absorption of regional expenditure budgets.

$\mathrm{H} 2$ : It is suspected that budget execution has an effect on the absorption of regional expenditure budgets.

H3: It is suspected that the procurement of goods / services ber influence on the absorption of regional expenditure budgets.

H4: It is suspected that the competence of human resources has an effect on the absorption of the regional budget.

H5: It is suspected that budget planning, budget execution, goods / services procurement and human resource competence simultaneously affect the absorption of regional expenditure budgets.

\section{RESEARCH METHODOLOGY}

This study uses primary data with a quantitative approach. The sample was firm by using purposive sampling technique. This research sample is 87 respondents who occupy the positions of head of finance, planning and expenditure treasurer within the regional apparatus organization of Palembang City. The data obtained were analyzed using descriptive analysis, instrument test, classical assumption test, multiple correlation analysis, coefficient of determination and hypothesis testing with the assistance of SPSS software.

\section{RESULT AND DISCUSSION}

\subsection{Result}

The results of the tests carried out showed a significance value of Asymp Sig (2-tailed) of 0.200 which means the significance is greater than $0.05(0.200>0.05)$. It can be concluded that the regression model fulfills the normality assumption, which means that the regression model is good and can be used. NThe tolerance value in the Budget Planning variable (X1) is 0.445, Budget Implementation (X2) is 0.421, Goods / Services Procurement (X3) is 0.463 and Human Resource Competence (X4) is 0.490 . These four variables produce a tolerance value that is greater than 0.10 . For the VIF value of these four variables, the VIF value is less than 10. So it can be concluded that there is no multicollinearity in this study, which means that the regression model is good and can be used because there is no correlation between the independent variables. Heteroscedasticity test results shows the dots spread 
randomly, namely above the number 0 and below the number 0 and the distribution of these points does not form a certain pattern like a wave so that it can be concluded that this study is free from heteroscedasticity symptoms.

Multiple Linear Regression Testing produces multiple linear regression equation model:
Budget Absorption $=5.145+0.465$ Budget Planning + 0.232 Budget Execution - 0.258 Procurement of Goods / Services +0.075 HR Competence $+\varepsilon$

The R Square value of 0.720 was obtained from testing the coefficient of determination (Table 1), indicating a very close relationship between the variable of independent and the variable of dependent.

Table 1.Result of Determination Coefficient Test (R Square)

\begin{tabular}{|c|c|c|c|c|}
\hline Model & $\mathrm{R}$ & $\mathrm{R}$ Square & Adjusted R Square & Std. Error of the Estimate \\
\hline 1 & $.848 a$ & .720 & .703 & 2,245 \\
\hline a. Predictors: (Constant), Human Resource Competence, Budget Planning, Procurement of Goods / Services, \\
Budget Execution
\end{tabular}

Source: SPSS Output, 2020

freedom degrees df $=n-(k+1)=72-(4+1)=67$ at $a=$ 0.05 is 1.996 .
Before interpreting the results of the partial significance test $(\mathrm{t}$ test) presented in table 2 , first determine the $\mathrm{t}$ table value obtained from the share of the $t$ distribution with

Table 2. $\mathrm{T}$ test results

\begin{tabular}{|c|c|c|c|c|c|c|}
\hline \multicolumn{7}{|c|}{ Coefficientsa } \\
\hline & & Unstandardize & Coefficients & Standardized Coefficients & & \\
\hline & Model & B & Std. Error & Beta & $\mathrm{t}$ & Sig. \\
\hline 1 & (Constant) & 5,145 & 4,584 & & 1,122 & .266 \\
\hline & Budget Planning & .465 & .071 & .634 & 6,543 & .000 \\
\hline & Budget Execution & .232 & .106 & .218 & 2,188 & .032 \\
\hline & $\begin{array}{c}\text { Procurement of goods / } \\
\text { services }\end{array}$ & -258 & .121 & -203 & $-2,138$ & .036 \\
\hline & $\begin{array}{l}\text { Human Resources } \\
\text { Competence }\end{array}$ & .075 & .072 & .096 & 1,045 & .300 \\
\hline
\end{tabular}

a. Dependent Variable: Budget Absorption

Source: SPSS Output, 2020

The t-count value of the budget planning variable is 6,543 with a critical estimation of 0,000 . In other words, the value of $t_{\text {count }}(6,543)>t_{\text {table }}(1,996)$ and a critical estimation $(0,000)<0.05$, so it is reasoned partially the budget planning variable significantly affects on budget absorption with a beneficial outcome. The t-count value of the budget implementation variable is 2.188 with a critical estimation of 0.032 . This means that the value of $\mathrm{t}$ count (2.188)> t table (1.996) and a significant value $(0.032)<0.05$, so it is persumed that mostly the budget execution variable has a critical estimation on budget absorption with a positive effect. The t-count value of the goods / services procurement variable is 2.138 with a significant value of 0.036 . In other words, the value of $\mathrm{t}_{\text {count }}(2.138)>\mathrm{t}$ table $(1.996)$ and a significant value (0.036) $<0.05$ so it is concluded that partially the variable procurement of goods/services has a significant effect on budget absorption with a negative effect. The $\mathrm{t}_{\text {count }}$ value of the human resource competency variable is 1.045 with a significant value of 0.300 . In other words, the value of $t_{\text {count }}(1.045)<t_{\text {table }}(1.996)$ and a significantly greater value $(0.300)>0.05$ so that partially the human resource competency variable has no effect on budget absorption.

The simultaneous significant test results ( $\mathrm{F}$ test) show the value of Fcount (43.038)> Ftable (2.509) and a significant value $(0.000)<0.05$. Simultaneously, the factord of budget planning, budget execution, goods / services procurement and human resources competence significantly affect budget absorption. The formula for finding the value of Ftable with df $1=\mathrm{k}-1$ or $5-1=4$ and df $2=$ nk or $72-5=67$ at $\mathrm{a}=0.05$ is obtained Ftable of 2.509 .

\subsection{Discussion}

Based on the partial test, it are often concluded that budget planning incorporates a significant effect on budget absorption in the regional apparatus of Palembang City. The slow absorption within the budget also indicates that the agency does not have a mature, clear and measurable planning concept (Sinaga, 2016). The absence of a budget planning concept in real terms will result in the emergence of a number of difficulties in directing the use of the budget on target. Meanwhile, Schiavo-Campo (in Zulaikah, 2019) states that a wellplanned budget can be implemented poorly, but a poorly planned budget cannot be implemented properly. Therefore, planning must be optimized so that bad conditions such as accumulation of budget absorption do not occur (Martini et al, 2020). 
Budget execution features a significant effect on budget absorption within the regional apparatus organization of Palembang City. Which means that budget execution has a crucial role in realizing government programs and activities. The implementation factor is one in every of the causes of the build up of expenditure budget realization at the top of the year (Sudarwati, 2017) and (Martini et al, 2019).

Partially, the procurement of products/services incorporates a negative and significant effect on budget absorption within the regional apparatus organization of Palembang City. Failure of the budget absorption target (Elim, 2018) related to the procurement of products and services disbursed by the government, it'll end in the loss of paying benefits because not all of the funds that are allocated will be utilized, which implies there's idle money (Martini et al, 2020). This can be when it's associated with physical development (facilities and infrastructure) for public facilities, then the impact of this delay will lead to delays within the benefits which will be received and enjoyed by the community.

Competence of human resources has no effect on budget absorption within the regional apparatus organization of Palembang city. This is supported by State research (2017) which states that human resource competence does not affect the low absorption of the budget. The problem is beacuse of frequent mutations or changes of officials related to financial management and late appointment of economic management officials. Wulandari (2018) states that the good or bad of a human resource competency possessed by some DPOs does not affect budget absorption.

The test results of the coefficient of determination R2 show the R Squer value of 0.720 which means there is a very close relationship between the variable of independent and the variable of dependent, while the remaining $28 \%$ caused by other variables not examined in this study. This condition indicates that budget planning, budget execution, goods/services procurement and competence of human resources simultaneously influence the absorption of regional expenditures in the regional apparatus organization of Palembang City.

\section{CONCLUSION}

Budget planning and budget execution contain a positive and significantly affect on budget absorption. Procurement of goods/services contains a negative and significantly affects on budget absorption, while human resource competence has no effect on budget absorption.

Palembang city government is expected In the future, the discussion process can be carried out with a process that does not take long so that the budget can be immediately ratified and optimizes the budget preparation process for activities carefully so that budget revisions do not occur so that budget execution can be carried out on time and there are flexible rules regarding the procurement of goods and services that allow implementation at the beginning of the fiscal year.

Further research it is suggested to add or replace independent variables so that they are more complete and varied. In addition, it is expected to use more complete data with a wider research sample.

\section{ACKNOWLEDGMENT}

The authors thankfully acknowledge scientific discussion with our colleagues from State Polytechnic of Sriwijaya, Indonesia. The authors would love to acknowledge the anonymous reviewers at the 4th FIRST 2020 International Conference for the feedback on earlier version of the paper, and also thank to the two anonymous reviewers who provided feedback as part of this proceeding review process.

\section{REFERENCES}

[1] Regional Financial and Asset Management Agency. 2020. Report on the Realization of the Palembang City Government Regional Revenue and Expenditure Budget for 2018 and 2019.

[2] Elim MA, Ndaparoka DS, and David TE. 2018. "Analysis of Factors Affecting the Absorption of the Expenditure Budget at Regional Apparatus Organizations in Kupang City". Journal of Accounting, Finance and Audit. Vol. 3 No.2, pp. 46-56.

[3] Halim, Abdul. 2016. Public Sector Financial Management problems of government revenue and expenditure. Edition 2. Jakarta: Four Salemba.

[4] Martini, R., Pembudi, Septian Bagus, Mubarok, M. Husni. 2019. “Analisis Kontribusi Retribusi Daerah terhadap Pendapatan Asli Daerah Kota Palembang”. Publikasi Penelitian Terapan dan Kebijakan, Vol. 2 (1), pp 90-95.

[5] Martini, R., Agustin, R., Zaliah, Z., \& Winarko, H. 2019. "Pendapatan Asli Daerah Provinsi Sumatera Selatan: dari Kontribusi Retribusi pasar." Jurnal Kajian Ekonomi dan Keuangan Daerah 5 (1): 58-71.

[6] Martini, R., Agustin, R., \& Sari, K. R. 2020. Accrual Discretion Policy on Excess/Less Budget Financing at the Provincial Level. TEST Engineering \& Management, 82, 9925-9935. 
[7] Martini, R., Sari, K. R., Somadi, T., \& Karman, I. W. 2019. "Financial Independence of the South Sumatra Regional Government" Proceedings of the International Conference On Applied Science and Technology 2019 - Social Sciences Track (iCASTSS 2019). 354, pp. 360-364. Denpasar: Atlantis Press. https://doi.org/10.2991/icastss19.2019 .75

[8] Country, Aji Surya Atma. 2017. Analysis of Factors Causing Low Budget Absorption in 7 Work Units in the Palembang KPPN Work Area.

[9] President of the Republic of Indonesia. Law Number 9 of 2015 concerning Regional Government.

[10] President of the Republic of Indonesia. Presidential Regulation Number 16 of 2018 concerning Government Procurement of Goods/Services.

[11] Ramdhani, Dadan and Indi Zaenur Anisa. 2017. "The Effect of Budget Planning, Quality of Human Resources and Budget Implementation on Budget Absorption in the Regional Apparatus Organization of Banten Province". Integrated Accounting Research Journal. Vol 10 No.1.

[12] Sinaga, Edward James. 2016. "Analysis of the Low Budget Absorption of Ministries/Institutions $(\mathrm{K} / \mathrm{L})$ and Local Government". Journal of Rechts Vinding Media for National Law Development, Vol. 5 No.2 PP 261-274.

[13] Sudarwati Nina, Herman Karamoy and Winston Pontoh. 2017. "Identification of Factors Accumulating Budget Realization at the End of the Year, (Case Study at the Manado Environment and Forestry Research and Development Center)". PP 129-138. Faculty of
Economics and Business, Sam Ratulangi University.

[14] Sudasri, David. 2016. The Effect of Budget Planning and Human Resource Competence on Empirical Study Budget Absorption at SKPD in Padang City. Padang State University.

[15] Sutrisno, Edy. 2019. Human Resources Management. Jakarta: Kencana Prenada Media Group.

[16] Wulandari, Riska 2018. The Effect of Budget Planning, Procurement of Goods / Services, and Competence of Human Resources on Budget Absorption in the Government of South Sumatra Province. Thesis. Sriwijaya State Polytechnic.

[17] Zaenur Anisa, Indi. 2017. "The Effect of Budget Planning, Quality of Human Resources and Budget Implementation on Budget Absorption in Banten Province Regional Apparatus Organizations". Tirtayasa Accounting Research Journal. Vol. 2 No.1.

[18] Zulaikah, Binti and Burhany, Dian Imanina. 2019. "Factors Affecting the Accumulation of Budget Absorption in the Fourth Quarter in Cimahi City". Industrial Research Workshop and National Seminar. PP 1221- 1234. Bandung State Polytechnic. 